\title{
EVALUASI KNOWLEDGE MANAGEMENT SYSTEM DI KOMPAS GRAMEDIA MENGGUNAKAN ANALISIS FAKTOR
}

\author{
Desi Maya Kristin; Wahyu Sardjono \\ Information Systems Department, School of Information Systems, Binus University \\ Jl. K.H. Syahdan No. 9, Palmerah, Jakarta Barat 11480 \\ d_10iya_sagirl@yahoo.co.id; wahyu.s@garuda-indonesia.com
}

\begin{abstract}
Evaluation of Knowledge Management System (KMS) is performed to determine the state of KM Portal and provide suggestions to improve the benefits and usability for employee and the company. The evaluation analysis of KMS uses factor analysis to determine the factors that influence user awareness in using KM Portal of Kompas Gramedia. The analysis shows three factors: the quality of KM Portal and user support; user participation; processes and procedures. All factors produced a model that can be used for the control of KM Portal. In accordance with the data processing, the current state of KM Portal is enough. This situation has not yet met the standards that company desires so the company needs further development to obtain a perfect score.
\end{abstract}

Keywords: knowledge management system, KM Portal, factor analysis

\begin{abstract}
ABSTRAK
Evaluasi Knowledge Management System (KMS) dilakukan untuk mengetahui keadaan KM Portal di Kompas Gramedia saat ini dan memberikan saran yang dapat meningkatkan manfaat dan daya guna KM Portal bagi karyawan dan perusahaan. Analisis evaluasi KMS menggunakan analisis factor untuk mengetahui faktor apa saja yang mempengaruhi kesadaran user dalam menggunakan KM Portal di Kompas Gramedia. Hasil analisis menunjukkan tiga faktor yang mempengaruhi kesadaran user untuk menggunakan KM Portal, yaitu kualitas KM Portal dan dukungan terhadap user, partisipasi user, serta proses dan prosedur perusahaan. Dari ketiga faktor ini dihasilkan model yang dapat digunakan untuk perhitungan keadaan KM Portal Kompas Gramedia saat ini. Sesuai dengan pengolahan data, keadaan KM Portal saat ini adalah cukup. Keadaan ini belum memenuhi standar keinginan perusahaan sehingga perlu dilakukan pengembangan selanjutnya untuk memperoleh nilai sempurna.
\end{abstract}

Kata kunci: knowledge management system, KM portal, analisis faktor 


\section{PENDAHULUAN}

Organisasi perlu menciptakan nilai dengan menerapkan pengetahuan tacit dan eksplisit ke dalam proses bisnisnya. Knowledge management (KM) merupakan penciptaan nilai yang dimaksud Kim (2002) dan menjadi metode yang memungkinkan untuk mencapai tujuan dan strategi perusahaan dengan mengembangkan inovasi yang terus-menerus (Forcadell, 2002).

Organisasi sering menyia-nyiakan sumber daya yang dimiliki dan menghamburkan uang hanya untuk mengulang kesalahan yang sama, menduplikasi proyek dan tidak menyadari pengetahuan (Robertson, 2002). Untuk menciptakan dan mempertahankan lingkungan berbagi pengetahuan, kriteria yang diperlukan oleh sebuah organisasi di antaranya adalah bagaimana organisasi mengelola, melaksanakan strategi berbagi pengetahuan, meningkatkan, mengembangkan konsep dan keterampilan berbagi pengetahuan, serta mendukung karyawan dalam melakukan aktivitas berbagi pengetahuan dengan membangun teknologi informasi dan teknik untuk berbagi pengetahuan. Cara atau sistem mengelola pengetahuan ini disebut Knowledge Management Systems (KMS). Para akademisi dan praktisi mengakui Knowledge Management semakin meningkatkan keunggulan kompetitif suatu organisasi (Sambamurthy dan Subramani, 2005).

Berdasarkan kebutuhan tersebut perusahaan Kompas Gramedia yang selanjutnya disingkat KG, membangun suatu KMS yang mengelola pengetahuan melalui Website interaktif, untuk memfasilitasi proses pembelajaran antar karyawan KG, baik secara online (Tanya jawab di website) yaitu portal SHAKE (Share Knowledge: "www.km.kompasgramedia.com") yang disebut KM Portal, maupun secara offline (dengan event/pertemuan/diskusi/seminar). Dengan adanya KM Portal, diharapkan dapat mengeksploitasi dan mengembangkan aset-aset pengetahuan perusahaan untuk mencapai tujuan perusahaan, serta mengerjakan sesuatu dengan lebih baik. KM Portal dibangun dan diterapkan di perusahaan untuk mendukung pembelajaran pengguna di perusahaan dan memenuhi kebutuhan pengguna akan informasi dan pengetahuan seputar pekerjaannya. Alasan utama untuk menerapkan KMS dalam organisasi bisnis menurut adalah kompetisi dan globalisasi; restrukturisasi dan downsizing; sharing of best practice; dan kesuksesan inovasi.

Dengan demikian, perusahaan KG berharap semua pengguna dapat mengoptimalkan KMS yang telah dibangun agar dapat memberikan kontribusi yang besar bagi perusahaan. Namun KG menilai KM Portal belum dapat digunakan secara maksimal. Oleh karena itu, perusahaan mengharapkan untuk dilakukan evaluasi terhadap penggunaan KMS untuk mengetahui faktor dan indikator dalam menyusun KMS yang sesuai dengan kebutuhan user.

Berdasarkan permasalahan tersebut, tujuan yang ingin dicapai melalui penelitian ini adalah menganalisis kinerja Knowledge Management System yang sedang berjalan dengan melihat dari aspek people, proses dan teknologi, mengetahui faktor-faktor apa saja yang mempengaruhi kesadaran user untuk menggunakan KM Portal KG, mengetahui indikator apa saja yang mempengaruhi kesadaran user untuk menggunakan KM Portal KG, mengetahui model yang terbentuk berdasarkan hasil evaluasi Knowledge Management System, memberikan gambaran dengan ditemukannya faktor-faktor, indikator-indikator, dan model yang mempengaruhi kesadaran user dalam menggunakan KM Portal KG. kepada pihak manajemen perusahaan.

Sedangkan manfaat penelitian yang diharapkan dapat dicapai melalui penelitian ini adalah untuk memberikan informasi kepada pihak manajemen KG mengenai hasil evaluasi KMS sehingga dapat dijadikan bahan pertimbangan dalam rangka meningkatkan daya guna atau memaksimalkan manfaat dari KMS bagi perusahaan dalam mencapai tujuan penerapan KMS, memberikan saran atau rekomendasi yang memungkinkan untuk meningkatkan kesadaran user dan melakukan pengembangan KMS yang lebih baik. 
Ruang lingkup pembahasan pada penulisan ini dibatasi hanya melakukan evaluasi dengan melakukan analisis terhadap faktor-faktor yang memperngaruhi kesadaran user dalam menggunakan KM Portal, hasil analisis tersebut akan dijadikan acuan untuk memberikan rekomendasi dari sisi people, process dan technology KMS kepada perusahaan. User yang dimaksud dalam penulisan ini adalah seluruh karyawan Kompas Gramedia yang dapat mengakses KM Portal KG karena telah memiliki account, dengan kata lain, telah didaftarkan sebagai pengguna KM Portal KG, evaluasi yang dilakukan terhadap KMS menggunakan analisis faktor, evaluasi yang dilakukan adalah evaluasi secara intangible.

Rumusan permasalahan yag akan dibahas adalah: (1) faktor-faktor apa saja yang mempengaruhi kesadaran user untuk menggunakan KM Portal KG?; (2) indikator apa saja yang mempengaruhi kesadaran user untuk menggunakan KM Portal KG?

\section{METODE}

Berikut adalah rancangan penelitian yang dilakukan (Gambar 1):

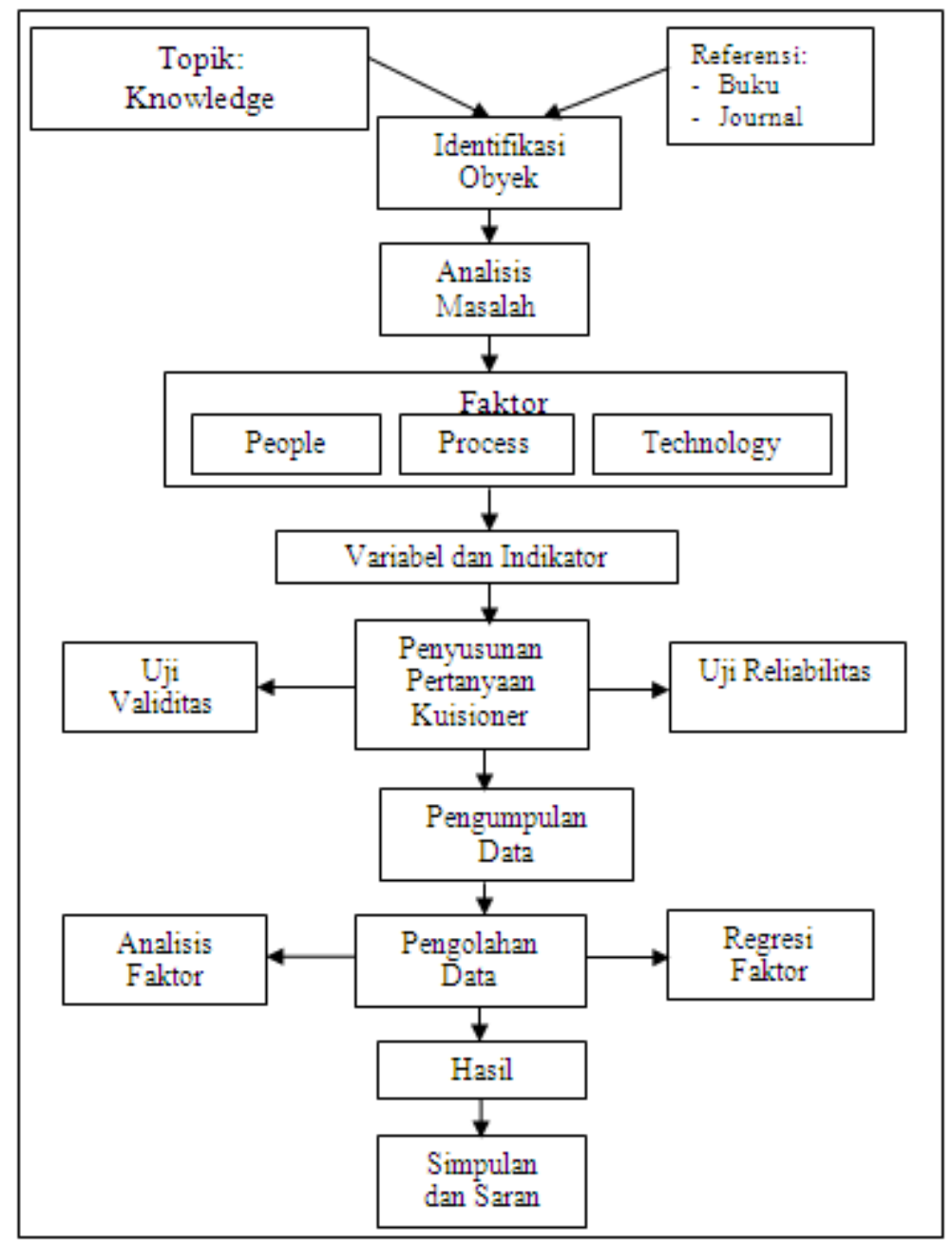

Gambar 1Desain penelitian 
Peneliti mencari tahu mengenai latar belakang dari KM Portal KG melalui wawancara kepada pihak perusahaan, studi pustaka (buku dan jurnal), dan observasi secara langsung terhadap KM Portal KG untuk mengetahui masalah yang ada kemudian dianalisis untuk mengetahui variabel yang akan dijadikan sebagai isi dari kuisioner yang akan dibagikan kepada responden berdasarkan factor-faktor komponen pembentuk Knowledge Management, yaitu people, process, dan technology.

Sebelum kuisioner dibagikan kepada responden, peneliti melakukan pengujian validitas dan reliabilitas terhadap kuisioner tersebut. Analisis dan evaluasi dilakukan berdasarkan data yang diperoleh melalui penyebaran kuisioner ke semua unit yang dijadikan sampel.

Setelah semua kuisioner didapatkan dari responden, kemudian dilakukan pengolahan data kuisioner tersebut dengan analisis faktor dan regresi faktor sampai didapat hasil penelitian. Kemudian dari hasil kuisioner tersebut dapat diolah sehingga dapat dijadikan dasar dalam membuat keputusan dan saran atau rekomendasi untuk pengembangan KM Portal KG selanjutnya agar menjadi lebih baik.

Di bawah ini adalah faktor, variabel, indikator dan pertanyaan dalam evaluasi KMS KG (Tabel 1)

Tabel 1 Faktor, Variabel, Indikator dan Pertanyaan dalam Evaluasi KMS KG

\begin{tabular}{|c|c|c|c|}
\hline Faktor & Variabel & Indikator & Pernyataan \\
\hline \multirow[t]{11}{*}{ People } & \multirow{4}{*}{$\begin{array}{l}\text { Partisipasi } \\
\text { dalam KMS } \\
\text { (McCuiston, } \\
\text { 2005; } \\
\text { Malhotra, } \\
\text { 2005) }\end{array}$} & \multirow{3}{*}{ Peran user } & $\begin{array}{l}\text { Responden mengajak karyawan lain untuk menggunakan } \\
\text { KM Portal. }\end{array}$ \\
\hline & & & $\begin{array}{l}\text { Responden akan menggunakan KM Portal meskipun tidak } \\
\text { ada himbauan/aturan. }\end{array}$ \\
\hline & & & $\begin{array}{l}\text { Responden akan menggunakan KM Portal meskipun tidak } \\
\text { ada reward (perhargaan dalam bentuk hadiah atau uang). }\end{array}$ \\
\hline & & $\begin{array}{l}\text { Technical } \\
\text { barriers }\end{array}$ & $\begin{array}{l}\text { Responden sulit untuk mengakses informasi/pengetahuan } \\
\text { di KM Portal. }\end{array}$ \\
\hline & \multirow{3}{*}{$\begin{array}{l}\text { Budaya dan } \\
\text { lingkungan } \\
\text { organisasi } \\
\text { (McCuiston, } \\
\text { 2005) }\end{array}$} & Accessibility & $\begin{array}{l}\text { Karyawan membutuhkan akses untuk berhubungan dengan } \\
\text { departemen lain. }\end{array}$ \\
\hline & & \multirow{2}{*}{$\begin{array}{l}\text { Openness of } \\
\text { communication } \\
\text { channel }\end{array}$} & $\begin{array}{l}\text { Perusahaan bersedia menyediakan saluran (wadah) yang } \\
\text { tepat untuk dapat berkomunikasi antar departemen. }\end{array}$ \\
\hline & & & $\begin{array}{l}\text { Perusahaan mengumumkan informasi atau pengetahuan } \\
\text { yang baru melalui KM Portal secara cepat. }\end{array}$ \\
\hline & \multirow{4}{*}{$\begin{array}{l}\text { Dukungan } \\
\text { terhadap user } \\
\text { (McCuiston, } \\
\text { 2005) }\end{array}$} & \multirow{2}{*}{ Training } & $\begin{array}{l}\text { Di dalam training yang pernah diikuti, peserta dianjurkan } \\
\text { untuk berbagi pengetahuan (sharing pengalaman). }\end{array}$ \\
\hline & & & $\begin{array}{l}\text { Training internal yang pernah anda ikuti menghimbau anda } \\
\text { untuk menggunakan KM portal. }\end{array}$ \\
\hline & & \multirow{2}{*}{$\begin{array}{l}\text { Reward atas } \\
\text { berbagi } \\
\text { pengetahuan }\end{array}$} & $\begin{array}{l}\text { Perusahaan memberikan reward kepada karyawan yang } \\
\text { berbagi pengetahuan (sharing) di KM Portal. }\end{array}$ \\
\hline & & & Tulisan anda di KM Portal dibalas dalam 3 hari kerja. \\
\hline \multirow[t]{6}{*}{ Process } & \multirow{3}{*}{$\begin{array}{l}\text { Knowledge } \\
\text { collect } \\
\text { (Weidner, } \\
\text { 2006) }\end{array}$} & $\begin{array}{l}\text { Knowledge } \\
\text { creation }\end{array}$ & $\begin{array}{l}\text { Responden menerapkan pengetahuan yang baru dari KM } \\
\text { Portal. }\end{array}$ \\
\hline & & $\begin{array}{l}\text { Knowledge } \\
\text { storage }\end{array}$ & $\begin{array}{l}\text { KM Portal saat ini, mencatat masalah dan solusi yang } \\
\text { pernah terjadi dalam perusahaan. }\end{array}$ \\
\hline & & $\begin{array}{l}\text { Knowledge } \\
\text { retention }\end{array}$ & $\begin{array}{l}\text { Informasi dan pengetahuan yang terdapat di KM Portal } \\
\text { saat ini selalu diperbaharui. }\end{array}$ \\
\hline & \multirow{3}{*}{$\begin{array}{l}\text { Knowledge } \\
\text { connect } \\
\text { (Weidner, } \\
\text { 2006) }\end{array}$} & $\begin{array}{l}\text { Knowledge } \\
\text { sharing }\end{array}$ & $\begin{array}{l}\text { Setiap karyawan memiliki kesempatan untuk berbagi } \\
\text { (sharing) pemecahan masalah / best practice yang telah } \\
\text { dipahami. }\end{array}$ \\
\hline & & \multirow{2}{*}{$\begin{array}{l}\text { Knowledge } \\
\text { utilization }\end{array}$} & $\begin{array}{l}\text { Informasi atau pengetahuan di KM Portal saat ini dapat } \\
\text { menjadi dasar pengambilan keputusan. }\end{array}$ \\
\hline & & & $\begin{array}{l}\text { Informasi atau pengetahuan di KM Portal saat ini dapat } \\
\text { meningkatkan kemampuan dalam melakukan pekerjaan. }\end{array}$ \\
\hline
\end{tabular}




\begin{tabular}{|c|c|c|c|}
\hline \multirow[t]{6}{*}{ Technology } & \multirow{6}{*}{$\begin{array}{l}\text { Desain dan } \\
\text { dukungan KM } \\
\text { Portal } \\
\text { (McCuiston, } \\
\text { 2005) }\end{array}$} & \multirow{4}{*}{$\begin{array}{l}\text { Kualitas fitur dan } \\
\text { konten KM } \\
\text { Portal }\end{array}$} & Bahasa yang digunakan KM Portal mudah dimengerti. \\
\hline & & & $\begin{array}{l}\text { Informasi atau pengetahuan di KM Portal saat ini mudah } \\
\text { ditemukan sesuai kebutuhan. }\end{array}$ \\
\hline & & & $\begin{array}{l}\text { Saat ini KM Portal memiliki informasi atau pengetahuan } \\
\text { yang lengkap. }\end{array}$ \\
\hline & & & Saat ini KM Portal memiliki fitur yang user friendly. \\
\hline & & \multirow{2}{*}{$\begin{array}{c}\text { Complexity } \\
\text { barriers }\end{array}$} & $\begin{array}{l}\text { Setiap bisnis unit atau divisi memiliki KMS (Knowledge } \\
\text { Management System) yang berbeda-beda sehingga } \\
\text { menyulitkan anda untuk mengakses pengetahuan. }\end{array}$ \\
\hline & & & $\begin{array}{l}\text { Saat ini KM Portal memiliki fitur yang kompleks sehingga } \\
\text { menyulitkan dalam pencarian informasi atau pengetahuan. }\end{array}$ \\
\hline
\end{tabular}

Variabel yang digunakan dalam penelitian ini ada dua, yaitu kesadaran user sebagai variabel terikat (dependent variable) dan partisipasi dalam KMS, budaya dan lingkungan organisasi, dukungan terhadap user, knowledge collect, knowledge connect, desain dan dukungan KM Portal sebagai variabel bebas (independent variable).

Populasi pada penelitian ini dibatasi hanya pada karyawan KG yang pernah menggunakan KM Portal KG. Sampel yang ditentukan dalam penelitian ini berjumlah 123 responden dari populasi 1300 orang.

Untuk melakukan analisis data pada penelitian ini ada serangkaian tahap yang akan dilakukan, yaitu: (1) uji Realibilitas dengan Cronbach Alpha; (2) uji kecukupan data dengan KMO-MSA; (3) uji korelasi variabel dengan Bartlett Test; (4) Analisis Faktor; (5) regresi faktor dari Analisis Faktor dengan faktor score.

\section{Reliabilitas, KMO-MSA \& Uji Bartlett}

Hasil penelitian disebut reliabel, bila terdapat kesamaan data dalam waktu yang berbeda (Sugiyono, 2008). Dalam menguji realibilitas variabel yang ada, penelitian ini menggunakan SPSS untuk mendapatkan nilai Cronbach Alpha. Nilai Cronbach's Aplha ini menunjukkan nilai rata-rata (average) korelasi antar item yang mengukur construct yang sama (Pallant, 2005). Menurut Nunnaly (1978 dalam Pallant, 2005) merekomendasikan nilai Alpha minimum adalah 0,7. Jika nilai Cronbach Alpha lebih besar dari 0,7 maka data dapat dikatakan reliable (Pallant,2005)

Uji KMO-MSA pada penelitian ini akan dilakukan dengan software applikasi SPSS. Apabila nilai KMO-MSA lebih besar dari 0,5 maka data telah cukup untuk difaktorkan.(Hair, et al., 2006). Pada penelitian ini Uji Bartlett dilakukan dengan menggunakan applikasi SPSS. Jika nilai Sig kurang dari $\alpha=0.05$ data belum cukup untuk difaktorkan.

\section{Metode Analisis Data}

Teknik skala yang digunakan dalam penelitian ini adalah intemized rating scales dengan menggunakan skala Likert (1-5) (Tabel 2). Skala likert digunakan untuk mengukur sikap, pendapat, dan persepsi seseorang atau sekelompok orang tentang fenomena sosial (Sugiyono, 2008).

Tabel 2 Skala Likert

\begin{tabular}{lll}
\hline & \multicolumn{1}{c}{ Jawaban } & Skor \\
\hline SS & Sangat Setuju & 5 \\
\hline S & Setuju & 4 \\
\hline
\end{tabular}




\begin{tabular}{lll}
\hline $\mathrm{N}$ & Netral & 3 \\
\hline $\mathrm{TS}$ & Tidak Setuju & 2 \\
\hline STS & Sangat Tidak Setuju & 1 \\
\hline
\end{tabular}

\section{HASIL DAN PEMBAHASAN}

\section{Uji Realibilitas}

Dengan menggunakan SPSS diketahui nilai Cronbach Alpha sebagai berikut (Tabel 3):

Tabel 3 Hasil Uji Realibilitas

\begin{tabular}{|r|r|}
\hline Cronbach's Alpha & N of Items \\
\hline .901 & 23 \\
\hline
\end{tabular}

Hasil uji realibilitas pada tabel 2 menunjukan koefisien alpha pada 23 variabel telah memiliki nilai sebesar 0.901 sehingga instrument yang digunakan dalam penelitian ini sudah dianggap reliable untuk pertanyaan-pertanyaan dalam masing-masing variabel yang digunakan dalam penelitian ini.

\section{KMO \& Bartlett's Test}

Berdasarkan Tabel 4 dapat diketahui bahwa asumsi kecukupan data telah terpenuhi dengan melihat nilai MSA dan KMO sebesar 0.884 pada output SPSS. Uji kecukupan data telah terpenuhi. Selain itu diketahui signifikansi pada Bartlett's test Sig. 0.000 kurang dari $\alpha 0.05$, yang artinya antar variabel telah saling berkorelasi.

Tabel 4 KMO and Bartlett's Test

\begin{tabular}{|l|r|r|}
\hline \multicolumn{2}{|c|}{ Kaiser-Meyer-Olkin Measure of Sampling Adequacy. } & .884 \\
Bartlett's Test of Sphericity $\quad$ Approx. Chi-Square & 1511.803 \\
& Df & 253 \\
& Sig. & .000 \\
\hline
\end{tabular}

\section{Anti Image Correlation}

Dengan memperhatikan output hasil pengujian SPSS pada tabel Anti-image Correlation, dapat diprediksi kesalahan variabel oleh variabel lain dengan ketentuan jika MSA $=1$, variabel dapat diprediksi tanpa kesalahan oleh variabel yang lain; MSA $>0,5$, variabel masih bisa diprediksi dan bisa dianalisis lebih lanjut; MSA $<0,5$, variabel tidak bisa diprediksi dan tidak bisa dianalisis lebih lanjut, atau dikeluarkan dari variabel lainnya. Dari hasil pengolahan yang didapat ditemukan 1 variabel yang bernilai dibawah 0,5 , maka variabel tersebut tidak dapat dianalisis lagi lebih lanjut, sedangkan variabel lainnya dapat terus diolah.

\section{Total Variance Explained}

Eigenvalues/characteristic roots digunakan untuk mengukur varian dari semua variabel pada faktor tersebut. Rasio dari Eigenvalues mengukur pentingnya faktor tersebut terhadap variabel. 
Pengujian pertama, dengan nilai eigenvalue $\geq 1$, maka terbentuk 5 faktor baru dari hasil analisis. Dimana hasil kumulatif dari ekstraksi varian sebesar 64,442 \%. Hasil kumulatif ini lebih besar dari $50 \%$, sehingga semua faktor tersebut masih valid. Peneliti juga melakukan uji 4 faktor, 3 faktor dan 2 faktor dan dihasilkan nilai kumulatif dari ekstraksi varian 4 faktor sebesar 59,713\%, nilai kumulatif dari ekstraksi varian 3 faktor sebesar 54,849 \% dan nilai kumulatif dari ekstraksi varian 2 faktor sebesar 49,372\%. Dilihat dari hasil pengujian tersebut maka untuk 2 faktor sudah tidak valid karena nilainya dibawah 50\%. Dan hasil sebaran terbaik adalah pada saat 3 faktor. Sehingga ketiga faktor inilah yang akan diproses untuk dianalisis lebih lanjut karena telah memenuhi kriteria tersebut.

\section{Component Matrix}

Setelah melakukan analisis terhadap faktor, terbentuklah faktor dan indikator baru untuk meningkatkan kesadaran user dan terjadi reduksi terhadap beberapa faktor dan indikator awal. Dalam penelitian ini indikator yang dimaksud adalah indikator yang dipakai untuk mengevaluasi Knowledge Management System. Faktor dan indikator tersebut dapat dilihat pada Gambar 2 sebagai berikut:

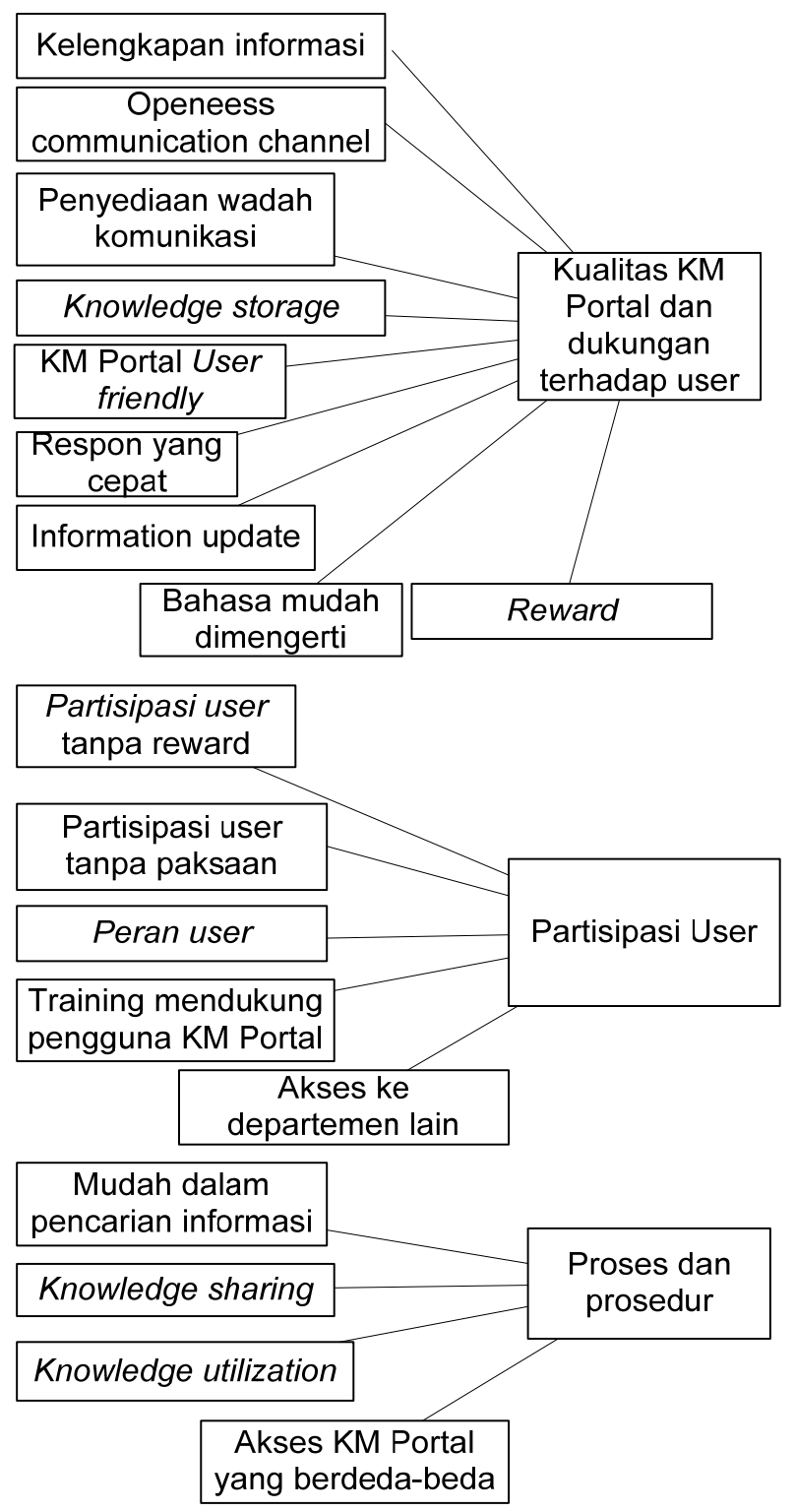

Gambar 2 Indikator dan faktor untuk meningkatkan kesadaran user 
Faktor pertama terbentuk dari indikator kelengkapan informasi, openness communication channel, penyediaan wadah komunikasi, knowledge storage, user friendly, respon, information update, bahasa mudah dimengerti dan reward. Faktor pertama diintepretasikan menjadi kualitas KM Portal dan dukungan terhadap user. KM Portal yang memiliki kelengkapan informasi, user friendly dalam penggunaannya, memiliki respon yang cepat, informasi yang update (tepat waktu) dan bahasanya mudah dimengerti menjadi kriteria penilaian kualitas KM Portal. Keterbukaan dan tersedianya saluran dan wadah komunikasi, serta adanya reward yang diberikan kepada user merupakan dukungan yang diperlukan terhadap user.

Faktor kedua terbentuk dari indikator partisipasi user tanpa reward dan partisipasi user tanpa paksaan, peran user, training mendukung pengguna KM Portal, dan akses ke departemen diinterpretasikan menjadi partisipasi user. Sikap kerelaan user dalam menggunakan KM Portal tanpa reward dan paksaan, adanya peran user, dan adanya training yang mendukung pengguna KM Portal , serta user yang melakukan akses ke departemen lain membutuhkan partisipasi user.

Faktor ketiga terbentuk dari indikator mudah dalam pencarian informasi, knowledge sharing, knowledge utilization, dan akses KM Portal yang berbeda-beda diinterpretasikan menjadi proses dan prosedur. Beberapa bisnis units atau functional units memiliki KMS yang berbeda sehingga banyaknya informasi yang tersimpan di dalamnya. Kemudahan pencarian informasi menjadi kebutuhan user dan informasi yang didapat perlu di sharing dan digunakan untuk membantu dalam pekerjaannya. Semua indicator tersebut terangkum sebagai proses KM dan prosedur perusahaan.

\section{Model yang Dipakai Untuk Melakukan Evaluasi Knowledge Management System}

Gambar 3 menunjukkan faktor yang digunakan untuk melakukan evaluasi KMS terhadap kesadaran user. Faktor-faktor terbentuk adalah kualitas KM Portal dan dukungan terhadap user, partisipasi user, serta proses dan prosedur. Untuk mendapatkan faktor yang lebih dominan dan harus diperhatikan, maka dilakukan regresi antara faktor-faktor tersebut dengan nilai terhadap KMS menurut responden yang didapatkan berdasarkan hasil kuisioner.

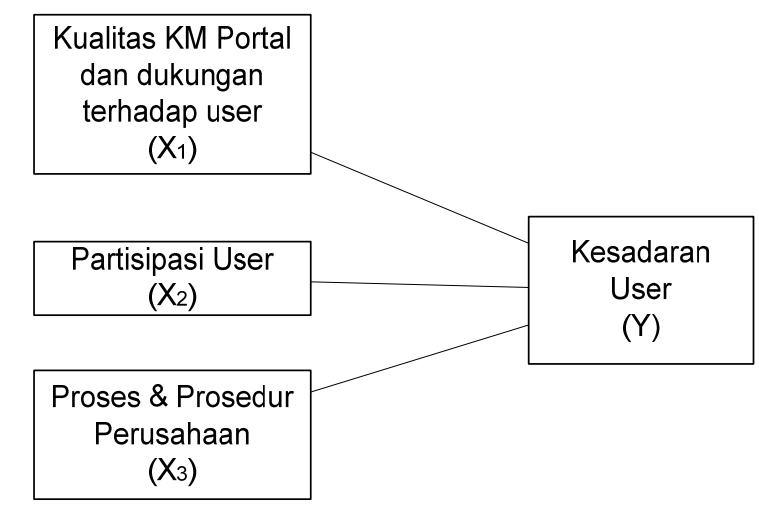

Gambar 3 Faktor yang digunakan untuk evaluasi KMS

Dalam kuisioner ditanyakan mengenai penilaian KM Portal secara keseluruhan dari 1-10 dengan kuantifikasi pada Tabel 5 berikut ini:

Faktor pertama sampai faktor ketiga memiliki nilai signifikansi dibawah $0,5 \%$, yaitu masingmasing 0,000, 0,001 dan 0,000; maka faktor tersebut reliable untuk masuk dalam model evaluasi KMS. 
Kemudian dilakukan perhitungan dan dari hasilnya didapat nilai faktor pertama $\left(\mathrm{X}_{1}\right)$ adalah 0,947 ; nilai faktor kedua $\left(\mathrm{X}_{2}\right)$ adalah 0,377 ; nilai faktor ketiga $\left(\mathrm{X}_{3}\right)$ adalah 0,467 ; dan nilai constant $(\mathrm{C})$ adalah 6,789. Berikut model yang tercipta dari evaluasi KMS adalah sebagai berikut:

$$
\mathrm{Y}=0,947 \mathrm{X}_{1}+0,377 \mathrm{X}_{2}+0,467 \mathrm{X}_{3}+6,789
$$

Tabel 5 Konversi Nilai Evaluasi KM Portal

\begin{tabular}{lr}
\multicolumn{1}{c}{ Skala } & Nilai \\
\hline Sempurna & 10 \\
\hline Sangat Baik & 9 \\
\hline Baik & 8 \\
\hline Cukup Baik & 7 \\
\hline Cukup & 6 \\
\hline Sedang & 5 \\
\hline Kurang & 4 \\
\hline Sangat Kurang & 3 \\
\hline Buruk & 2 \\
\hline Sangat Buruk & 1 \\
\hline
\end{tabular}
berikut:

Dari model tersebut, maka dapat digambarkan model evaluasi KMS pada Gambar 4 sebagai

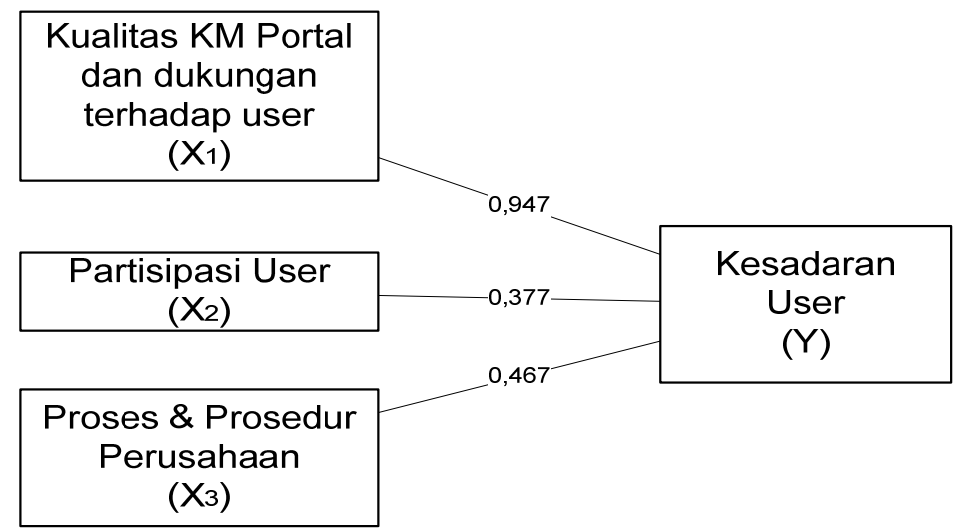

Gambar 4 Faktor nilai yang digunakan untuk evaluasi KMS

Dari gambar di atas dapat diketahui faktor pertama $\left(\mathrm{X}_{1}=\right.$ Kualitas KM Portal dan dukungan terhadap user) bernilai positif 0,947 , maksudnya adalah peningkatan kualitas KM Portal yang termasuk kelengkapan informasi, openness communication channel, penyediaan wadah komunikasi, penyimpanan pengetahuan (knowledge storage), KM Portal yang user friendly, respon yang cepat, informasi yang update, penggunaan bahasa yang mudah dimengerti, dan reward yang akan diberikan kepada user akan mempengaruhi 0,947 pada peningkatan kesadaran user dalam penggunaan KM Portal.

Faktor kedua $\left(\mathrm{X}_{2}=\right.$ Partisipasi User $)$ bernilai positif 0,377 , menunjukkan setiap peningkatan pada faktor proses dan prosedur perusahaan yang termasuk partisipasi user tanpa reward, partisipasi user tanpa paksaan, peran user, training yang mendukung pengguna KM Portal, dan akses ke departemen lain akan mempengaruhi peningkatan 0,377 kesadaran user terhadap penggunaan KM Portal. 
Faktor ketiga $\left(\mathrm{X}_{3}=\right.$ Proses dan prosedur) bernilai positif 0,467 . Hal ini berarti setiap ada peningkatan pada faktor dukungan terhadap pengguna KM Portal yang meliputi mudah dalam pencarian informasi, knowledge sharing, knowledge utilization, dan akses KM Portal yang berbedabeda akan mempengaruhi peningkatan 0,467 mengenai kesadaran user terhadap penggunaan KM Portal.

\section{Evaluasi Knowledge Management System}

Dari faktor nilai dan model tersebut dapat diketahui evaluasi kesadaran user terhadap penggunaan KM Portal, kemudian faktor tersebut dilakukan regresi faktor untuk mendapatkan nilai maksimum dan minimum. Dengan melakukan regresi faktor tersebut, maka di dapat nilai minimum faktor $\mathrm{X}_{1}=-3,18497$, faktor $\mathrm{X}_{2}=-2,33683$, dan faktor $\mathrm{X}_{3}=-2,50464$ serta nilai maksimum faktor $\mathrm{X}_{1}$ $=2,63485$, faktor $X_{2}=2,61354$, dan faktor $X_{3}=3,11620$. berikut:

Dari regresi faktor tersebut, didapatkan batasan dari nilai minimum dan maksimum sebgai

dengan

$$
Y=0,947 X_{1}+0,377 X_{2}+0,467 X_{3}+6,789
$$

$-3,18497 \leq \mathrm{X}_{1} \leq 2,63485$

$-2,33683 \leq \mathrm{X}_{2} \leq 2,61354$

$-2,50464 \leq X_{3} \leq 3,11620$

\section{PENUTUP}

Semua indikator tersebut terangkum sebagai proses KM dan prosedur perusahaan.tabel 6 memuat nilai evaluasi kesadaran user dalam penggunaan KM Portal.

Tabel 6 Nilai Evaluasi Kesadaran User dalam Penggunaan KM Portal

\begin{tabular}{lrrrrrr}
\hline & \multicolumn{1}{c}{$\mathbf{X}_{\mathbf{1}}$} & \multicolumn{1}{c}{$\mathbf{X}_{\mathbf{2}}$} & \multicolumn{1}{c}{$\mathbf{X}_{\mathbf{3}}$} & $\mathbf{C}$ & \multicolumn{1}{c}{$\mathbf{Y}$} \\
\hline Saat ini & 0 & 0 & 0 & 6,789 & 6,789 \\
\hline Minimum & $-3,18497$ & $-2,33683$ & $-2,50464$ & 6,789 & 1,72218 \\
\hline Maksimum & 2,63485 & 2,61354 & 3,11620 & 6,789 & 11,72477 \\
\hline
\end{tabular}

Berdasarkan tabel di atas kemungkinan yang terjadi terhadap evaluasi kesadaran user dalam mengggunakan KM Portal adalah: (1) kondisi saat ini dimana tidak ada penambahan atau pengurangan pada faktor X1 (Kualitas KM Portal dan dukungan terhadap user), X2 (Partisipasi user), dan X3 (Proses dan prosedur), sehingga evaluasi KMS saat ini memiliki nilai 6,789. Jika dikuantifikasikan, kondisi KM Portal saat ini adalah cukup; (2) saat semua faktor yang ada berkurang atau mengalami penurunan dari keadaan saat ini dan semua faktor mencapai titik terendah dengan nilai -3,18497 untuk faktor $\mathrm{X}_{1}$, nilai $-2,33683$ untuk faktor $\mathrm{X}_{2}$, dan nilai $-2,50464$ untuk faktor $\mathrm{X}_{3}$. Maka dari itu kondisi KM Portal dapat dikategorikan menjadi sangat buruk; (3) kondisi bila semua faktor ditingkatkan secara bersamaan hingga mencapai titik tertinggi dengan nilai 2,63485 untuk faktor $\mathrm{X}_{1}$, nilai 2,61354 untuk faktor $\mathrm{X}_{2}$, dan nilai 3,11620 untuk faktor $\mathrm{X}_{3}$. Pada kondisi saat itu $\mathrm{KM}$ Portal dapat dikuantifikasikan menjadi sempurna.

Bagi perusahaan KG, peneliti menyarankan untuk: (1) meningkatkan manfaat dan daya guna KM Portal dengan meningkatkan kesadaran user; (2) meningkatkan kualias KM Portal - perusahaan dapat memenuhi kelengkapan informasi dan pengetahuan dalam KM Portal. Mulai dari pengetahuan 
umum yang dapat menambah pengetahuan setiap user sampai pengetahuan yang lebih terstruktur sesuai dengan kebutuhan setiap business unit atau functional unit bahkan pengetahuan yang lebih spesifik hanya untuk bidang tertentu; (3) cepat dalam merespon postingan user di forum diskusi dalam KM Portal dan melakukan update informasi agar user tertarik untuk membuka KM Portal; (4) memperkaya isi dari FAQ dengan pertanyaan yang sering ditanyakan dan jawaban yang mudah dimengerti; (5) memberikan reward kepada user yang aktif sebagai pemicu kesadaran user; (6) memasukkan materi training ke dalam KM Portal dan melibatkan pekerjaan karyawan dalam KM Portal;

Berdasarkan keterbatasan yang dimiliki dalam penelitian ini, untuk penelitian selanjutnya peneliti menyarankan untuk: (1) memperluas variabel penelitian mengingat penelitian ini terbatas hanya terfokus pada kesadaran user; (2) meningkatkan jumlah sampel dan menurunkan taraf kesalahan.

\section{DAFTAR PUSTAKA}

Forcadell, Francisco J. and Guadamillas, Fatima. (2002). A case study on the implementation of a knowledge management strategy oriented to innovation. Knowledge and Process Management, 9 (3), 162.

Hair, J. F., Anderson, R. E., Tatham, R. L. dan Black, W. C. (2006). Multivariate Data Analysis (6 ${ }^{\text {th }}$ edition). Harlow: Prentice Hall UK.

Kim Yong Jin, Chaudhury, A., Rao, H Raghav. (2002). A knowledge management perspective to evaluation of enterprise information portal. Knowledge and Process Management, 9 (2), 57 71.

Malhotra, Yogesh. (2005). Intergratif knowledge management technologies in organizational business processes: getting real time enterprises to deliver real business performance. Journal of Knowledge Management, 9 (1), 7 - 28.

McCuiston, Velma E. (2005). Knowledge management implementation: HR executives speak out. Proquest Journal of Applied Management and Entrepreneurship, 10 (1), 20.

Pallant, Julie. (2005). SPSS Survival Manual. Sidney: Ligare.

Robertson, S. (2002). A tale of knowledge sharing systems. Journal of Knowledge Management, 6 (3), 295-308.

Sambamurthy, V. dan Subramani, M. (2005). Special issue in information technologies and knowledge management. MIS Quarterly, 29 (1), 1 - 7.

Sugiyono. (2008). Metode Penelitian Bisnis. Bandung: Alfabeta.

Weidner, Douglas. (2006). Certified Knowledge Manager Handout. Washington: KM Institute International. 